\section{Potential Productivity of Marrow Stem and Thousand-headed Kale}

SEeD of marrow stem kale was sown in August and the plants transplanted to permanent quarters in October. Approximately half of the plants flowered in the following spring. The non-flowering plants continued their vegetative growth and were sampled by the 'perfect plant method' in the following October. Dry-matter production (excluding roots) was equivalent to $\mathbf{9 \cdot 7}$ (from an August 4 sowing) and $7 \cdot 6$ (from an August 19 sowing) tons per acre. If we neglect the weight of the plants at transplanting time this represents a complete year's production of dry matter. Plants from later August and September sowings, transplanted in April, produced by October 8.6 and 6.2 tons of dry matter (excluding roots) per acre. Comparable production figures for thousandheaded kale from these later sowings were $7 \cdot 7$ and $6 \cdot 2$ tons. These figures represent a production of dry. matter two or three times as great as that obtained when the kales are sown in the traditional manner in April, and much in excess of that obtained with other agricultural crops. They may be compared with the annual dry matter production of $\mathbf{7 \cdot 6}$ for the evergreen Pinus $^{1}, 3 \cdot 2$ for birch ${ }^{2}$, and $1 \cdot 6-5 \cdot 6$ tons per acre for natural herbaceous vegetation ${ }^{3}$.

The high productivity of the kales undoubtedly results from their early development of a full leaf cover, the autumn-transplanted marrow stem kale having a mean leaf area index of 0.4 by early May and one of approximately $2 \cdot 0$ by the end of that month, which compares with a leaf-area index of 0.06 at that date for a commercial crop sown in April as is customary, and which yielded $3 \cdot 3$ tons of dry matter per acre.

Botany Department,

University of Manchester.

'Ovington, J. D., Ann. Bot., N.S., 21, 287 (1957).

Ovington, J. D., and Madgeworth, H. A. I., Plant and Soil, 10, 271 (1959).

s Pearsall, W. H., and Gorham, E., Oikos, 7, 193 (1956).

\section{Cytochrome $c$ Oxidase, the Terminal Oxidase of Iris pseudacorus L.}

WHILE it is generally agreed that cytochrome $c$ oxidase is the terminal oxidase of embryonic plant tissues, some workers doubt if it has this role in older plant tissues as well ${ }^{1}$. It is of interest that a mature tissue such as the rhizome of Iris pseudacorus L., obtained from a Lancashire marsh, should contain a cytochrome system which might reasonably be claimed to account for the oxygen uptake of the tissue. 'The rhizome tissue used was cut from within the endodermis of the current year's growth, $1 \cdot 0 \mathrm{~cm}$. or farther from the meristematic region. The cells were typical parenchymatous cells except that the tissue also contained some vascular cells.

The presence of a cytochrome system was apparent from the absorption spectra of slices of reduced tissue when examined with a direct-vision spectroscope. The positions of the maxima of the absorption bands in the visible region corresponded approximately with the $\left(a+a_{3}\right)_{\alpha}, b_{\alpha}$ and $c_{\alpha}$ cytochrome bands of a reduced yeast suspension with which they were compared, except that the $b_{\alpha}$ and $c_{\alpha}$ bands of the Iris tissue were not distinctly separated.

Cores of tissue were used for respiration experiments. These cores $1 \mathrm{~cm}$. diameter and $2.5 \mathrm{~cm}$. long

Table 1. THe EFFECT OF CARBon MONOXIDE/OXYGEN AND NrTROGEN/ OXYGEN GAS MIXTURES ON THE KESPIRATION OF ITis RHIZOME AND

\begin{tabular}{cc} 
Organisms & \multicolumn{1}{c}{$\begin{array}{c}\text { BAKER'S Y Inhibitor } \\
\text { InhT }\end{array}$} \\
Rhizome tissue & $\left\{\begin{array}{l}95 \text { per cent carbon monoxide/ } \\
5 \text { per cent oxygen in dark } \\
95 \text { per cent carbon monoxide/ } \\
5 \text { per cent oxygen in light }\end{array}\right.$ \\
Baker's yeast & $\left\{\begin{array}{l}95 \text { per cent carbon monoxide/ } \\
5 \text { per cent oxygen in dark } \\
95 \text { per cent carbon monoxide/ } \\
5 \text { per cent oxygen in light }\end{array}\right.$
\end{tabular}

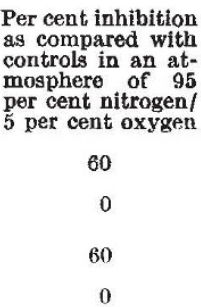
as compared with controls in an atper cent nitren 5 per cent oxygen$$
0
$$

0

were split lengthways, rinsed and used immediately. The uptake of oxy gen of the 'half-cores' was measured in Warburg manometers at $10^{\circ}$ in a damp atmosphere of 95 per cent carbon monoxide/5 per cent oxygen or 95 per cent nitrogen $/ 5$ per cent oxygen both in the light (250-W. mercury vapour lamp) and in the dark. A suspension of baker's yeast in $0.1 M$ phos. phate buffer, $p \mathrm{H}$ 6.0, was also used as a comparison and the dark carbon monoxide inhibition was 60 per cent in both cases and fully reversed in the light (Table 1).

It is generally accepted that cytochrome $c$ oxidase is the terminal oxidase of baker's yeast and the fact that a similar light-reversed carbon monoxide inhibition of 60 per cent was obtained with Iris is evidence that a similar state of affairs exists in this tissue. These results would support the widely held view that eytochrome $c$ oxidase forms the main terminal oxidase even in mature plant tissues ${ }^{2}$.

\section{G. G. Henshaw \\ D. A. Coult \\ D. BOULTER}

Hartley Botanical Laboratories, University of Liverpool.

' Lundegårdh, H., in Encyclopaedia of Plant Physiology, 12/1, 311, edit. W. Kuhland (Springer Verlag, 1960).

${ }^{2}$ Smith, L., and Chance, B., Ann. Rev. Plant Physiol., 9, 449 (1958).

\section{GERONTOLOGY}

\section{Rate of Senescence}

WE owe to Minot ${ }^{1}$ a startling paradox-the view that the rate of senescence is most rapid at the beginning of life and slowest at the end: to quote the fourth of the laws by which he summarized his conclusions, "Senescence is at its maximum in the very young stages and the rate of senescence diminishes with age". The justification for his view was that the intrinsic or specific growth-rate of the tissues decreases most rapidly at the outset and progressively more slowly afterwards, following a roughly exponential die-away curve (Fig. 1,A). It seemed a reasonable assumption that the senescent state is related to the loss of the power of growth and so the paradox has been widely accepted, notwithstanding the intuitive conviction that the process of senescence is not significant until after the prime of life. The postulated initial, rapid stages of senescence have to be shrugged off as 'insensible'.

However, there are properties relevant to senescence which can be measured and which are not found to increase most rapidly at the outset : the specific death-rate, for example, is minimal not at the outset but in late childhood; it then begins to increase slowly, with progressive acceleration ${ }^{2}$, and not most rapidly at first. It is therefore worth 